\title{
Acute Effect of Centella Asiatica on Quinalphos Induced Toxicity on the Whole Brain of Catla Catla
}

\author{
Prince Prathaban .K ${ }^{1}$, Saravanan.$T^{2}$
}

\begin{abstract}
Quinalphos is an organic phosphate that induces toxic effects on catla catla. The acute induced toxic effects on brain of the catla catla have been studied. Brain plays the pivotal role on signaling the metabolism. Quinalphos is a nuerotoxic compound, hence been chosen for the study. The Lc50 value of the quinalphos used in this study is $0.2 \mu l / 30$ liters of water. The antidote used is centella asiatica. (nuero-stimulator), the amount used is $300 \mathrm{mg} / 30$ liters. The result reflect the effect of quinalphos on protein, carbohydrates, lipids, which has been overcome by the antidote.
\end{abstract}

Keywords: QUINALPHOS, CENTELLA ASIATICA, Antidote, CATLA CATLA, BRAIN.

\section{Introduction}

The catla catla is an important and integral part of daily intake of the people of India. The people who cannot afford the luxury of the sea fishes settle for fresh water fishes. The frequent uses of pesticides in agriculture practices pollute the soil, hydro soil and water bodies thus reaching the aqua ecosystem. The aquatic environment is subjected to an ever increasing range of pollutants, reflecting mor rapid innovations of our technology to manufacture goods to satisfy the demand. More than $50 \%$ of the Indian population is dependent on agriculture.

Indiscriminate uses of pesticide wastes that runs into the lake, river and the canal etc., causes serious effect on the metabolism of the fishes.

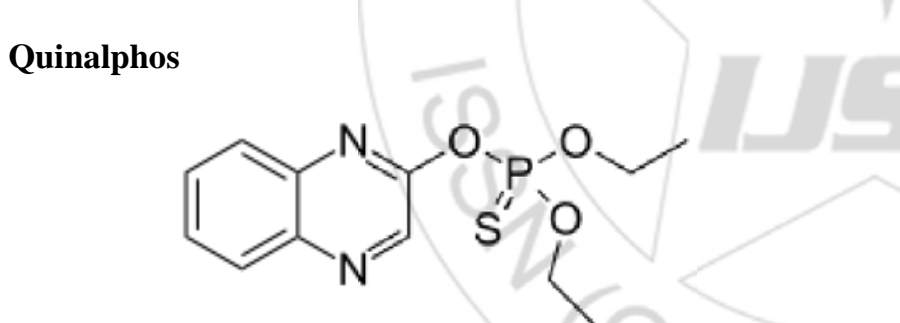

Quinalphos is an organic compound. The chemical formula is $\mathrm{C}_{12} \mathrm{H}_{15} \mathrm{~N}_{2} \mathrm{O}_{3} \mathrm{PS}$, IUPAC name is 0,0-diethyl 0-quinoxalin 2-yl phosphorothioate. It is widely used in india for wheat, rice, sugarcane and cotton. Many organophosphates are potent neurotoxins, functioning by inhibiting the action of AChE in nerve cells. Neurotransmitters such as acetylcholine (which is affected by organophosphate pesticides) are profoundly important in the brain. The primary effect of quinalphos and other Ops on vertebrate and invertebrate organisms is the inhibition of AChE activity, the enzyme that degrades the neurotransmitter acetylcholine in cholinergic synapses (pan and dutta, 1998). Duration of exposure, type of OP, as well as species of catla catla has an effect on the extent of AChE expression. Acetylcholine (Ach) is the only classical neurotransmitter that after release into the synaptic cleft is inactivated by enzymatic hydrolysis rather than by reuptake. As a consequence, ACh has a turnover rate in vivo that is much higher than that of any other transmitter, including catecholamines and amino acids (haubrich and Chippendale, 1977).
AChE was identified as the enzyme responsible for termination of cholinergic transmission by cleavate of Ach to acetat and choline: AChE is found in cholinergic synapses in the brain as well as in autonomic ganglia, the neuromuscular junction, and the target tissues of th parasympathetic system (silman and sussman, 2005). Inhibition of the AChE activity results in a buildup of acetylcholine causing proonged excitatory postsynaptic potential.This results in repeated, uncontrolled firing of neurons leading to hyperstimulation of the nerve/muscle fibers, which leads to paralysis, sometimes death. Contamination of aquatic ecosystems by sub-lethal levels of quinalphos is fairly common and had serious impact on nontarget Catla catla.

\section{ANTIDOTE:}

Centella is used as a leafy green in south indian cuisine, where it is vallarai. Used as a memory booster. It is also known as an excellent antioxidant.

\section{Literature Survey}

A survey was taken in and around Tambaram to find out the major pesticide that is been used. The survey resulted in administration of quinalphos.

The ecological changes occurring in the water body are always best indicated by biochemical parameters of aquatic organisms, like carbohydrate, protein and lipids (Kumarasamy, P et al., 2013, Somaiah, K. Sunita, K. and Nagaraju, B. et al., 2014).

Protein being essential nutrition for growth and development which inturn serves as energy source during stress. Decreasing trends have been reported in the brain of O.mossambicus exposed to quinalphos (durairaj and selvarajan 1992).

Lipids are generally triglycerides that metabolize the reserve energy source. Methylparathion exposed Barbus chonchonius. Hence the above parameters are considered and effort of re stabilization with help of antidote Centella asiatica or 'vallarai' is known to be used in wound healing, memory improvement and in the process of treating mental fatigue. The oxidative deterioration of lipid-containing food is responsible for rancid odours. 


\section{International Journal of Science and Research (IJSR) \\ ISSN (Online): 2319-7064}

Index Copernicus Value (2013): 6.14 | Impact Factor (2014): 5.611

Many phenolic compounds particularly flavonoids, exhibits wide range of biological effects ( zainol .M.K et al., 2002). Studies also show that some of these compounds or potent disposers of free radicals, and prevention against neurodegenerative disease.

\section{Materials and Methods}

Catla catla was stocked in the tanks of 500 liters capacity irrespective of sex and the average weight is to be $4 \mathrm{~g}$ and length is to be $7 \mathrm{~cm}$. They are grouped has three separate entities.

Group 1: served as control.

Group 2: served as experiment (quinalphos alone)

Group 3: served as antidote (quinalphos+vallarai)

\section{CHEMICALS}

Quinalphos (lipids): a redish brown liquid, and that used in this study was a commercial grade (75\%).

Dried form of powdered c. asiatica, commercial

Catla catla were bought from poondi government farm, and acclimatized for 10 days. The Catla catla were fed with the combination of tubifex (dried and alive). The size of them is almost the same with the slight difference of $1 \mathrm{~cm}$.

The whole brain has been taken for the present study, and

following parameters were carried out:

- Estimation of proteins

- Estimation of lipids

- Estimation of carbohydrates

Acute toxicity was study was conducted for 24 hours, 48 hours, 72 hours and 96 hours.

\section{Estimation of Total Proteins}

Proteins were estimated following the procedure (lowry et al.,1951) using folin phenol reagent.

\section{Principle:}

Trichloroacetic acid (TCA) was used to precipitate the protein. The carbamyl group of the protein reacts with the copper and potassium of the reagent to give the blue colored copper potassium biuret complex. This complex together with tyrosine and tryptophan present in the proteins reduces the phosphomolybdate of the folinciocaulteau reagent to intensify the colour of the solution which is directly proportional to concentration of the protein.

\section{Reagents}

1) $5 \%$ tricholoracetic acid (TCA)-5gms of TCA dissolved in $100 \mathrm{ml}$ of distilled water.

2) $1 \mathrm{~N}$ sodium hydroxide- 4gms of sodium hydroxide was dissolved in $100 \mathrm{ml}$ of distilled water.

3) $0.1 \mathrm{~N}$ sodium hydroxide- $400 \mathrm{mgs}$ of sodium hydroxide was dissolved in $100 \mathrm{ml}$ of distilled water.

4) Solution A-2g of sodium carbonate was dissolved in $100 \mathrm{ml}$ of $0.1 \mathrm{~N}$ sodium hydroxide.

5) Solution B- $500 \mathrm{mg}$ of copper sulphate was dissolved in $1 \%$ sodium or potassium tartarate to be prepared fresh.

6) Solution C- $100 \mathrm{ml}$ of solution A and $2 \mathrm{ml}$ of solution B were mixed.

7) Folin phenol reagent - diluted with equal volume of distilled water in 1:1 ratio

\section{Procedure}

$20 \mathrm{mg}$ of the different tissues were weighed, homogenized separately and precipitated in $2 \mathrm{ml}$ of TCA. The precipitate was centrifuged for 5 minutes at 3000rpm. The tissues were taken and dissolved in $1 \mathrm{ml}$ of $1 \mathrm{~N} \mathrm{NaoH}$. To $0.5 \mathrm{ml}$ of the sample; $5 \mathrm{ml}$ of solution $\mathrm{C}$ was added and mixed rapidly after 10 minutes $0.5 \mathrm{ml}$ of the folin phenol reagent was added and the colour intensity was measured in the spectrophotometer at $540 \mathrm{~nm}$ after 20 minutes.

Using th blank, standard bovine serum albumin and the test samples, the colour intensity was measured and the amount of protein calculated following the formula given below.

$$
\frac{\text { OD of the sample }}{\text { OD of the STD }}-\frac{100}{\text { WT of sample }}=\mathrm{mg} \%
$$

\section{Estimation of Lipid}

\section{Principle}

This method is based on the sulpho-phospho vanillin reaction which depends on the reaction of lipid with sulphuric , phosphoricavcid and vanallin reagent to give red colour .

\section{Reagents}

Vallanin reagent:

2 gms of vanillin powder was dissolved in $800 \mathrm{ml}$ of $89 \%$ ortho phosphoric acid; $200 \mathrm{ml}$ of distilled water was added.

- Chloroform: Methanol in ratio of 2:1

- 0.9 \%Sodium Chloride: $900 \mathrm{mg}$ of sodium chloride was dissolved in $100 \mathrm{ml}$ of distilled water

\section{Procedure}

$5 \mathrm{mg}$ of (brain) was taken and homogenized in the homogenizer with $5 \mathrm{ml}$ of chloroform: methanol. To this $0.5 \mathrm{ml}$ of $0.9 \%$ sodium chloride was added and centrifuged for 10 mins. The lower part was separated from the from the fluff $0.5 \mathrm{ml}$ of the extract was taken in the sterilized syringe and left for evoperation..

After evaporation $0.5 \mathrm{ml}$ of $0 \mathrm{f}$ conc. Sulphuric acid was added, placed in water bath for 10.mins, cooled at room temperature. To this vallanin reagent $(2.5 \mathrm{ml})$ wa sadded the testube was allowed to stand for 30 mins. The intensity of the colour developed is read at $520 \mathrm{~nm}$, using spectrometer. Standard and blank were prepare simultaneously using standard cholesterol (Merck) and concentrated sulphuric acid. Standard solution of cholesterol in $100 \mathrm{ml}$ of 2:1 chloroform, and methanol was prepared.

This was diluted to 1:10 in solvent prior to the experiment. Amount of lipid in the samples was calculated.

The values are expressed as $\mathrm{mg} \%$.

\section{Estimation of Carbohydrate}

\section{Materials}

- $2.5 \mathrm{NHC1}$

- Standard glucose: stock, dissolve $100 \mathrm{mg}$ in $100 \mathrm{~mL}$ water. Working standard-10mL of stock diluted to $100 \mathrm{~mL}$ with distilled water. Store refrigerated after adding a few drops of toluene. 


\section{International Journal of Science and Research (IJSR) \\ ISSN (Online): 2319-7064 \\ Index Copernicus Value (2013): 6.14 | Impact Factor (2014): 5.611}

- Phenol 5\% redistilled (reagent grade ) phenol (50g) dissolved in water and diluted to one liter.

- Sulphuric acid 96\% reagent grade.

- Standard glucose: stock-100 mg in $100 \mathrm{~mL}$ of water. Working standard-10mL of stock diluted to $100 \mathrm{~mL}$ with distilled water.

\section{Procedure}

Weigh 100mg of the sample into a boiling tube.

1) Hydrolyse by keeping it in a boiling water bath for three hours with $5 \mathrm{~mL}$ of $2.5 \mathrm{~N} \mathrm{HCl}$ and cool to room temperature.

2) Neutralize it with solid sodium carbonate until the effervescence ceases.

3) Make up the volume to $100 \mathrm{~mL}$ and centrifuge.

4) Pipette out $0.2,0.4,0.6,0.8$, and $1 \mathrm{~mL}$ of the working standard into a series of test tubes.

5) Pipette out 0.1 and $0.2 \mathrm{~mL}$ of the sample solution in two separate test tubes. Make up the volume in each tube to $1 \mathrm{~mL}$ with water.

6) Set a blank with $1 \mathrm{~mL}$ of water.

7) Add $1 \mathrm{~mL}$ of phenol solution to each tube.
8) Add $5 \mathrm{~mL}$ of $96 \%$ sulphuric acid to each tube and shake well.

9) After 10 min shake the contents in the tubes and place in a water bath at $25-30^{\circ} \mathrm{C}$ for $20 \mathrm{~min}$.

10) Read the color at $490 \mathrm{~nm}$.

11) Calculate the amount of total carbohydrate present in the sample solution using the standard graph.

Absorbance corresponds to $0.1 \mathrm{~mL}$ of the test $=\mathrm{mg}$ of glucose $100 \mathrm{~mL}$ of the sample solution contains $=$

$\mathrm{X}$ x 100mg glucose

0.1

$=\%$ of total carbohydrate present.

\section{Results}

The results reflect the effect of quinalphos on three parameters, namely protein, carbohydrate, and lipid. This effect has been overcome by the use of C.asiatica, which proved to be an excellent antidote due to the phenolic and neuro-stimulating agent.

Table showing the efeect of qunal phos toxicity on the total amount of carbohydrate, protein and lipid

\begin{tabular}{|c|c|c|c|c|c|c|c|c|c|}
\hline \multirow{2}{*}{ EXPOSURE } & \multicolumn{3}{|c|}{ PROTEIN (mg\%) } & \multicolumn{3}{c|}{ LIPID (mg\%) } & \multicolumn{3}{c|}{ CARBOHYDRATE } \\
\cline { 2 - 11 } & GRPI & GRP II & GRP III & GRPI & GRPII & GRPIII & GRP I & GRP II & GRP III \\
\hline 24 HOURS & 40.14 & 2.74 & 6.56 & 10.24 & 9.58 & 10.11 & 24.1 & 21.39 & 15.15 \\
\hline 48 HOURS & 40.14 & 0.06 & 1.386 & 10.24 & 9.36 & 10.15 & 24.1 & 21.21 & 23.27 \\
\hline 72 HOURS & 40.14 & 0.06 & 1.75 & 10.24 & 4.5 & 10.18 & 24.1 & 20 & 23.87 \\
\hline 96 HOURS & 40.14 & 0.02 & 2.04 & 10.24 & 4.5 & 10.23 & 24.1 & 5.75 & 24 \\
\hline
\end{tabular}

Graph Showing the Effect of Pesticide and Antidote Ror The Total Protien Content

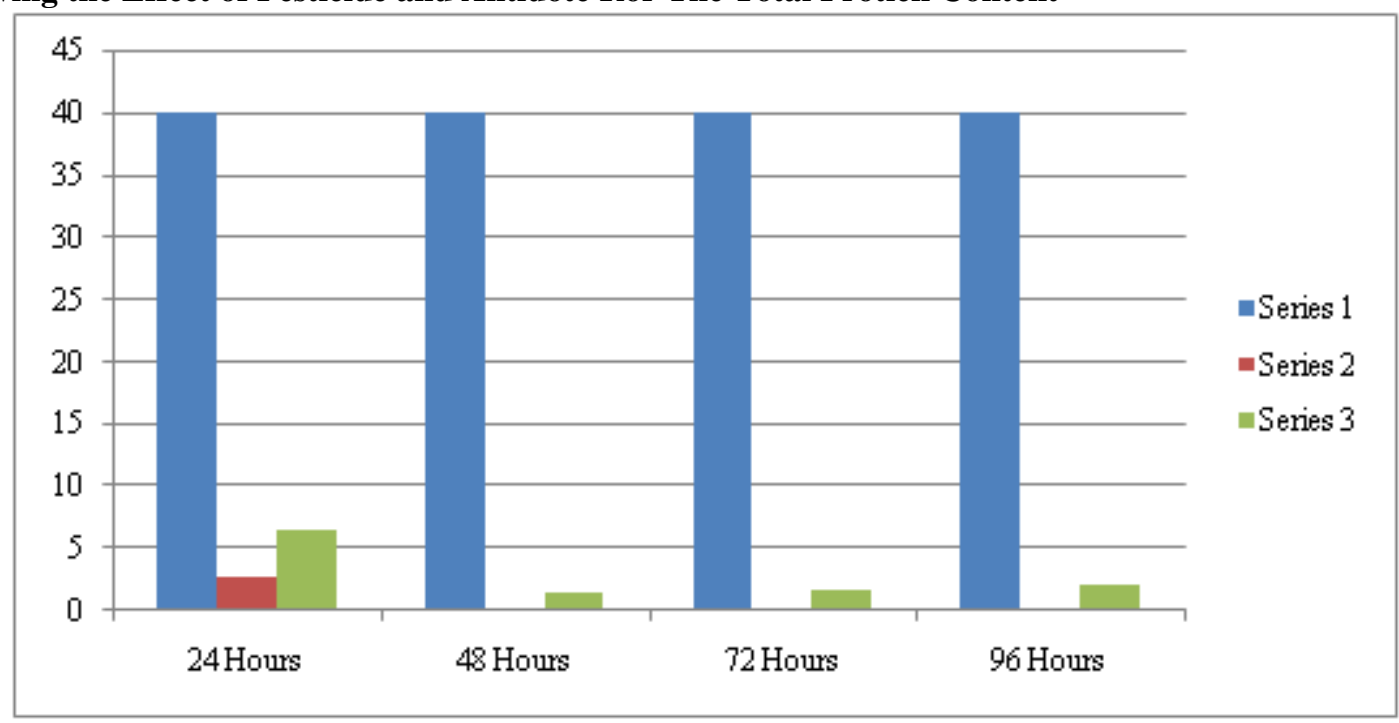

\section{Protiens}

After the exposure of 24 hours of catla catla, there was a drastic decrease in the amount of proteins in grpII. There is also a controlled recovery with groupIII; when compared with the grpI. There is also a control effect on the recovery with grpIII, the value slightly increased while comparing with the grpI.
During 48 hours the amount of protein shows much greater reduction in the protein level when compared with grp1. The antidote once again seems effective to raise the level.

During 72 hours, the study shows the revival of the lost protein with an optimum quantity. This shows the antidote is very effective on the grpIII.

During 96 hour, the study shows the drastic decrease in the level of protein grpII, even the antidote its self is able to 


\section{International Journal of Science and Research (IJSR) \\ ISSN (Online): 2319-7064}

Index Copernicus Value (2013): 6.14 | Impact Factor (2014): 5.611

slightly reduce only to the considerable when compared to grpI.

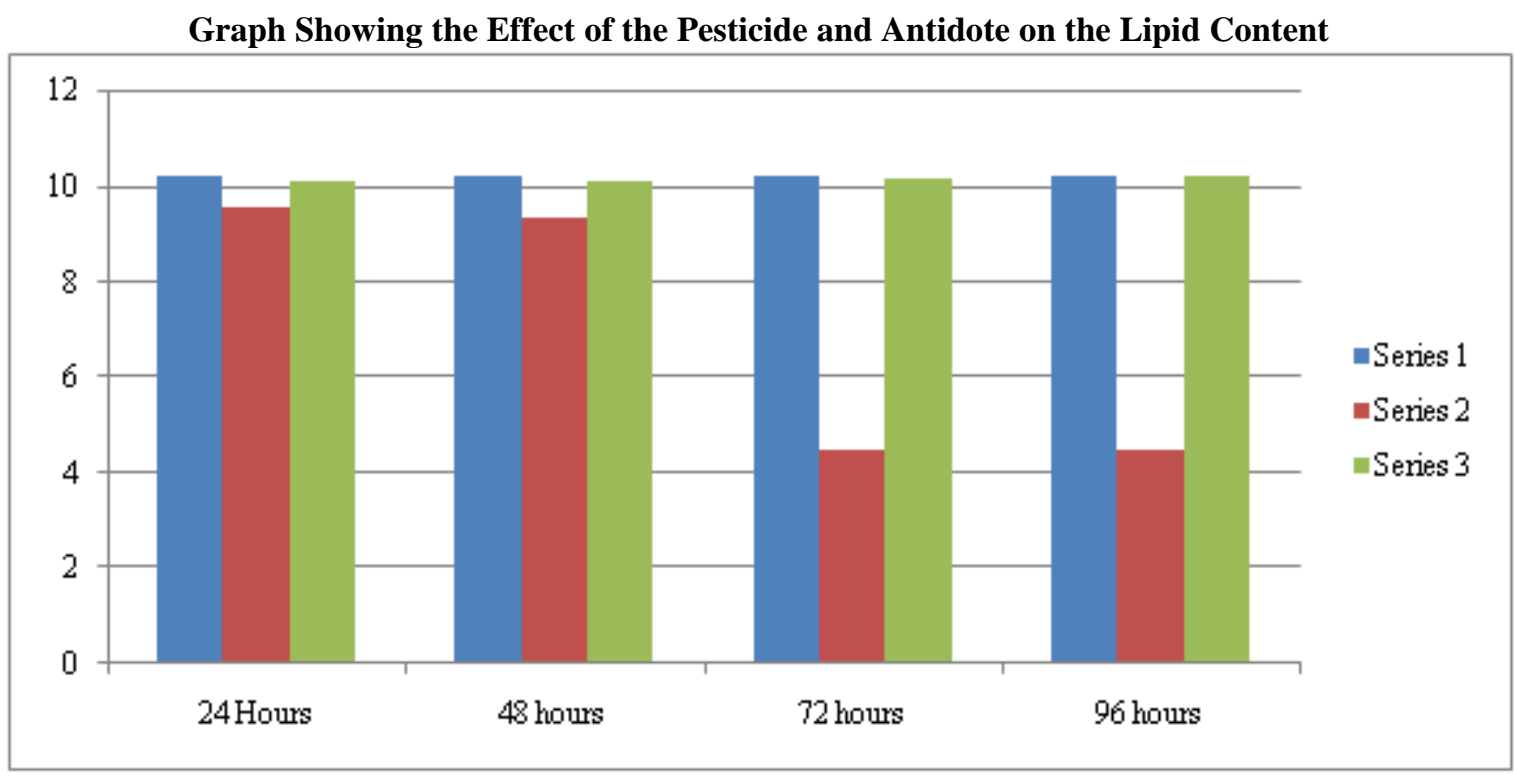

\section{Lipid}

During 24 hours, the study of the catla catla, shows slight decrease in the lipid level compared to the grp1, and the action of the antidote in recovering nearly to the grp1. During 48 hours, the shows the slight decline as seen in the 24 hours, but on the slightest increase on the other hand the antidote recovers. During 72 hours, the study shows the drastic reduction to $5 \mathrm{mg} \%$, while the grpIII values shows the recovery to $10.18 \mathrm{mg} \%$ when compared with that of control the 96 hours study shows a stable decline where as the antidote is positively to almost the grpI. Antioxidative activities among the accessions tested. Results also showed that both leaf and root of C. asiatica had high antioxidative activity, which was as good as that of a-tocopherol. The total phenolic content, determined according to the folin-ciocalteu method, varied from 3.23 to $11.7 \mathrm{~g} / 100 \mathrm{~g}$ dry sample, and showed strong association $(\mathrm{r} 2=0.90)$ with antioxidative activity. The results suggest that phenolic compounds are the major contributors to the antioxidative activities of C.asiatica.

\section{Graph Showing Effect of Pesticide and Antidote on the Total Content of Cabrbohydrate.}

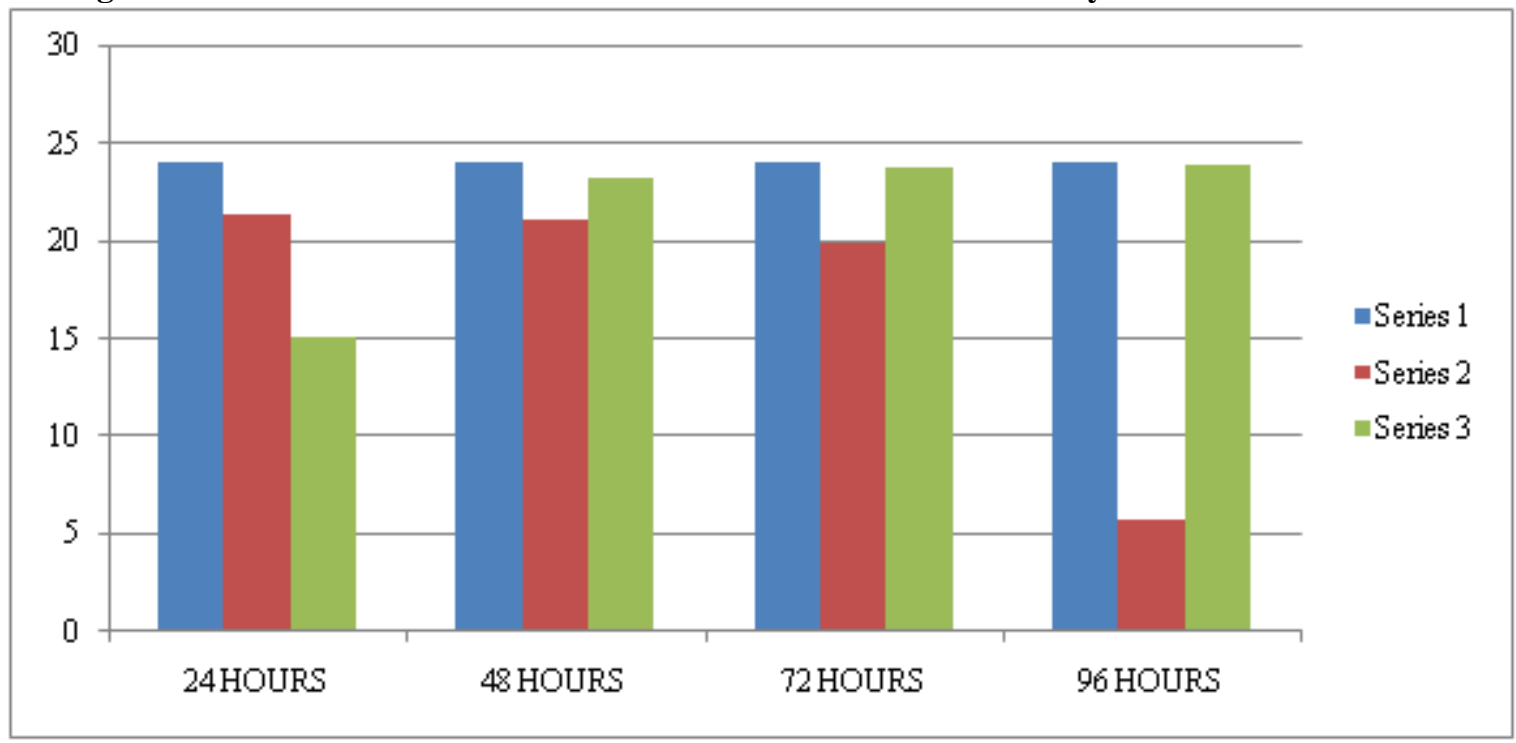

\section{Carbohydrate}

During, 24 hour, the study shows the slight decrease in the level when compared with grpI, grpIII shows a recovery to match almost the gpr1value. During 48 hours, the study shows the decrease in the amount of carbohydrate in grpII, when compared to the grpII, but grpIII shows recovery of the amount equal to grpI. During 72, hours the study shows the decline of 20 the grpIII shows the recovery of 23.87mg\%. During 96, the hours study shows alarming decrease, which has been recovered in the groupIII.

\section{Conclusion}

The above study shows that the decrease in the protein, carbohydrates, and lipid in the brain of catla catla. The 


\section{International Journal of Science and Research (IJSR) \\ ISSN (Online): 2319-7064 \\ Index Copernicus Value (2013): 6.14 | Impact Factor (2014): 5.611}

purpose of the study the decrease in the nutritional value of the catla catla

In view of the importance of catla catla to diet of man, it is necessary that biological monitoring of the water and catla catla meat for consumption should be done regularly to ensure continuous safety of the fresh water food. Safe disposal of domestic sewage and industrial effluents should be practiced and recycled to avoid these metals and other contaminants from going into the environment. The study showed a need for continuous pollution assessment study of aquatic organisms in fresh water body.

I sincerely thank Dr.Gladies Kezhia, for being a source of great support and knowledge although out the study. I also thank Mr. T. Saravanan my partner for being an inspiration source.

\section{Future Scope}

This work of mine will be a good source to start with, for the people who really care for the environment, fishes, and nutrition for poor at the same time. The metabolism and nutritional value is always the field of work for any researcher, as fishes are the bio markers.

\section{References}

[1] Annamalai M, Chokkalingam k, Manoharan S, Mathan R, Siddqyi A, sreekrishnan T. (2001) aquatic toxicity from pulp and paper mill effluents, environ res, 5, 175196.

[2] Abd hamida, zainola M, Yusofb S, Muse R. (2009) Antioxidative activity and total phenolic compounds of leaf, root and petiole of four accessions of centella asiatica(L.), 2, 130-135.

[3] Aruldoss, indra N and Sankar S. (2010) original article impact of lead and influence of different feeds on carbohydrate metabolism in the muscle tissue of fresh water fish, oroechromis mossambicus, 65, 12-19.

[4] Biotechnology in animal husbandry, 2009 institute for animal husbandry, Belgrade-25(3-4), P 241-249.

[5] Couillard CM, Berman RA, Panisset JC (1988). Histopathology of rainbow trout exposed to a bleached kraft pulp paper mill effluent. Environ. Contam, toxicol., 17:319-323.

[6] Dehadrai P.V, Mukhopadhyay P.K. and (1980) biochemical changes in the air breathing cat catla catla, clarias batrachus (Linn.) exposed to malathion. Environ.poll. 22(A): 149-158.

[7] Dwivedi A, Mishra A, Tripathi C, Dubey V. acute toxicity and behavioral response of freshwater fishy, Mystus vittatus exposed to pulp mill effluent. Journal of environmental chemistry,and ecotoxicology. 2011; 3(6): 167-172.

[8] Kumar S, gopal K. (2001). Impact of distillery effluent on physiological consequences in the fresh water teleost Channa punctatus. Bull.Environ. contam. Toxicol., 66: 617-622.

[9] Guillermo Garcia-manero, Hui yang1, carlos buesoramos. (1998) phase1 study of the histone deacetylase inhibitor vorinostat (suberoylanilide hydroxamic acid) in patients with advanced leukemias and myelodysplastic syndromes, biological me, 76, 98-123.

[10] Mclelay DJ, GordonMR, Praveen, Santosh Kumar, Pramila singh, Departmenet of Biosciences, Indian Kinetic Analysis of of the invivo Inhibition of liver AChE in air brathing fish Clarias bratrachus.

[11]D, Mehaboob, Janet, M.V.neurobehaviral responces of the freshwater teliost Cyprinus carpio under quinqlphos intoxification 2009.

[12] B.Nagaraju \& Lethal, sublethal effects of quinqlphos on nucleic acids of freshwater Lebeo rohita. Aug 2013

[13] Muthukumaravel, k., shivakumar.,B. Kumaraswamy,P. and Govindarajan, studies on the toxicity of pestiside monocrotophos on the biochemical constituents of fresh water Catla catla labeo rohita 2013

[14] Praveen(2004, ) neurobehavioral responces of the freshwater teleost, Cyprinus carpio. Under quinalphos intoxication, 65,78-80.

[15] Venkata rathnamma $V$, nagaraju $B(2011)$ impact of quinolphos on dna and rna content of the freshwater catla catla, labeo rohita(Hamilton), 23, 89-93.

[16] Tripathi C, dwivedi A and dubey V (2013) acute toxicity and behavioral response of freshwater catla catla, mystus vittatus exposed to pulp mill effluent, food nutrition, 28, 43-47. 